\title{
Transformation of Epichloë typhina by electroporation of conidia
}

\author{
James E Dombrowski ${ }^{1}$, James C Baldwin², Steve C Alderman ${ }^{1}$, Ruth C Martin ${ }^{1 *}$
}

\begin{abstract}
Background: Choke, caused by the endophytic fungus Epichloë typhina, is an important disease affecting orchardgrass (Dactylis glomerata L.) seed production in the Willamette Valley. Little is known concerning the conditions necessary for successful infection of orchardgrass by E. typhina. Detection of E. typhina in plants early in the disease cycle can be difficult due to the sparse distribution of hyphae in the plant. Therefore, a sensitive method to detect fungal infection in plants would provide an invaluable tool for elucidating the conditions for establishment of infection in orchardgrass. Utilization of a marker gene, such as the green fluorescent protein (GFP), transformed into Epichloë will facilitate characterization of the initial stages of infection and establishment of the fungus in plants.
\end{abstract}

Findings: We have developed a rapid, efficient, and reproducible transformation method using electroporation of germinating Epichloë conidia isolated from infected plants.

Conclusions: The GFP labelled E. typhina provides a valuable molecular tool to researchers studying conditions and mechanisms involved in the establishment of choke disease in orchardgrass.

\section{Introduction}

Orchardgrass (Dactylis glomerata L.) is an important forage grass species. About $97 \%$ of orchardgrass seed used for pastures and hay in North America is produced in the Willamette Valley in western Oregon. Choke disease, caused by the endophytic fungus Epichloë typhina, was first reported in the Willamette Valley during the mid 1990s [1]. Infected plants remain asymptomatic during most of the year. In the spring, E. typhina proliferates within reproductive tillers, encasing the developing seed head in a dense mycelial mat (stroma). However, the stem continues to grow, revealing an elongated, white stromal mass that resembles a small cattail. Conidia of one or two mating types are produced on the surface of each stroma. Fertilization requires the transfer of conidia of one mating type to stroma of the opposite mating type. This is typically accomplished by flies in the genus Botanophila [2]. Following fertilization, perithecia develop within the stroma surface $[3,4]$. The perithecia produce ascospores, which are dispersed by

\footnotetext{
* Correspondence: Ruth.Martin@ars.usda.gov

'USDA-ARS National Forage Seed Production Research Center, 3450 S.W. Campus Way, Corvallis, OR 97331 USA

Full list of author information is available at the end of the article
}

wind and cause new plant infections. The pathogen has not been shown to be transmitted through the seed in orchardgrass, but it is seed transmitted in other grasses [3-6].

The recent introduction and rapid spread of choke disease is a serious problem for orchardgrass seed producers in the Willamette Valley $[1,7,8]$. In England, where the disease has occurred for many years, the number of fields with choke disease increased from zero to a few during the first year of production to $33-81 \%$ by the second to fifth year of seed production [9]. In France, choke was reported to affect up to $30 \%$ of the tillers in a field by the fourth year of seed production $[10,11]$. Since the first incidence of choke reported in Oregon in the mid 1990s [1], the fungus has spread to $\sim 90 \%$ of orchardgrass seed production fields and has caused yield losses of up to 65\% in individual fields [8].

Very little is known about the conditions necessary for successful infection of orchardgrass by E. typhina. Fertilization of the fungal stroma is facilitated by flies $[2,12]$, but fly density was not correlated with reproductive success of the fungus in western Oregon $[2,13]$. Fertilization of E. typhina by ascospores has been reported recently and may contribute to the rapid spread of choke in

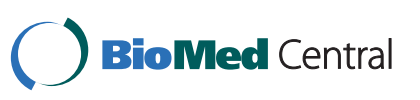

(c) 2011 Dombrowski et al; licensee BioMed Central Ltd. This is an Open Access article distributed under the terms of the Creative Commons Attribution License (http://creativecommons.org/licenses/by/2.0), which permits unrestricted use, distribution, and reproduction in any medium, provided the original work is properly cited. 
orchardgrass [14]. Attempts to infect orchardgrass foliage or flowers with conidia or ascospores were not successful [4]. Germination of E. typhina ascospores and conidia on the cut ends of seed stalks of orchardgrass and growth of hyphae down the pith has been reported [4-6], although it was not established whether these plants ultimately became infected through the stalks. Infection of young tillers by ascospores or conidia produced by ascospores under very favorable experimental conditions was recently reported [15]. It is not known when or how infections occur in the field or how long the latent period is between infection and manifestation of symptoms in the field.

Detection of E. typhina early in the disease cycle can be difficult due to sparse distribution of hyphae in the plant. Therefore a sensitive method to detect the fungus in plants would provide an invaluable tool for elucidating the conditions and establishment of the infection in orchardgrass. Green Fluorescent Protein (GFP) has been utilized extensively as a marker to aid in the development of fungal transformation systems and to examine early stages in plant/fungal interactions [reviewed in [16], [17-22]]. Translation fusions between GFP and fungal genes of interest have also been utilized to determine gene expression patterns and to investigate the role of specific genes in the infection process $[16,23]$. Transformation of E. typhina with the GFP marker gene will facilitate the characterization of the initial stages of infection and progression of the disease in plants [16]. There are several different methods available for fungal transformation, such as chemical induction, Agrobacterium-mediated transformation, particle bombardment and electroporation [[16,24-27], reviews and references within, [28,29]]. Chemical transformation of protoplasts of Epichloë festucae has been reported and was used to determine the expression patterns of the lolitrem biosynthetic genes [30] and to look at the infection process of E. festucae in Lolium perenne [31]. Electroporation of germinating conidia has been used successfully to transform a range of fungal species [32-34]. We report here a simple and rapid method using electroporation to transform germinating Epichloë conidia isolated from infected plants. The GFP labelled E. typhina provides a valuable molecular tool for researchers studying the infection process in orchardgrass. The transformation protocol will also be valuable for gene function studies in Epichloë-plant interactions.

\section{Materials and methods}

\section{Transformation vector}

The pCT74 GFP expression vector [16] was used as an intact circular plasmid or as a linearized plasmid for transformation experiments. The plasmid was digested overnight at $37^{\circ} \mathrm{C}$ with Xho I to linearize the plasmid. The digested DNA was precipitated with $1 / 10$ volume of
$3 \mathrm{M} \mathrm{NaOAc}, \mathrm{pH} 5.2$, and 2 volumes of EtOH. One $\mu \mathrm{L}$ of blue dextran $(10 \mathrm{mg} / \mathrm{mL})$ was added to aid in visualization of the pellet. The precipitated DNA was resuspended in sterile distilled water at a final concentration of $0.5 \mu \mathrm{g} / \mu \mathrm{L}$.

\section{Collection and preparation of conidia for transformation}

Orchardgrass plants known to be infected with E. typhina were grown in the greenhouse under $16 \mathrm{hr}$ of light at $21^{\circ} \mathrm{C}$. To induce flowering, the plants were vernalized in a growth chamber at $8^{\circ} \mathrm{C}$ with $8 \mathrm{hr}$ of light for 12 weeks, then at $15^{\circ} \mathrm{C}$ for 2 additional weeks under $18 \mathrm{hr}$ of light, and then returned to the greenhouse. Conidia from newly formed unfertilized stromata (Figure 1) were collected in about $10 \mathrm{~mL}$ of sterile water using a sterile artist paintbrush. The brush was dipped into sterile deionized water, gently brushed along the surface of each stroma to collect conidia in the brush, then shaken in the water to dislodge the spores. Approximately $10^{6}$ conidia $/ \mathrm{mL}$ were obtained when conidia from 5-10 stroma were collected in one tube. Isolated conidia were gently shaken in sterile deionized water for $4 \mathrm{hr}$ at room temperature at which time $>90 \%$ of the conidia had germinated (Additional File 1). Suspended germinated conidia were transferred into sterile microfuge tubes $(1.5 \mathrm{~mL} /$ tube $)$ and centrifuged at $\sim 16,000 \times \mathrm{g}$ for $45-60 \mathrm{~s}$. Approximately $1.45 \mathrm{~mL}$ of the supernatant was discarded. The conidia were resuspended in cold sterile electroporation buffer $(1 \mathrm{mM}$ Hepes, $50 \mathrm{mM}$ mannitol, $\mathrm{pH}$ 7.5) to a final volume of $1 \mathrm{~mL}$.

\section{Sensitivity of untransformed conidia to hygromycin B}

The plasmid used for transformation contains the hygromycin B phosphotransferase gene which confers resistance to hygromycin and enables the selection of transformed colonies. To determine the concentration

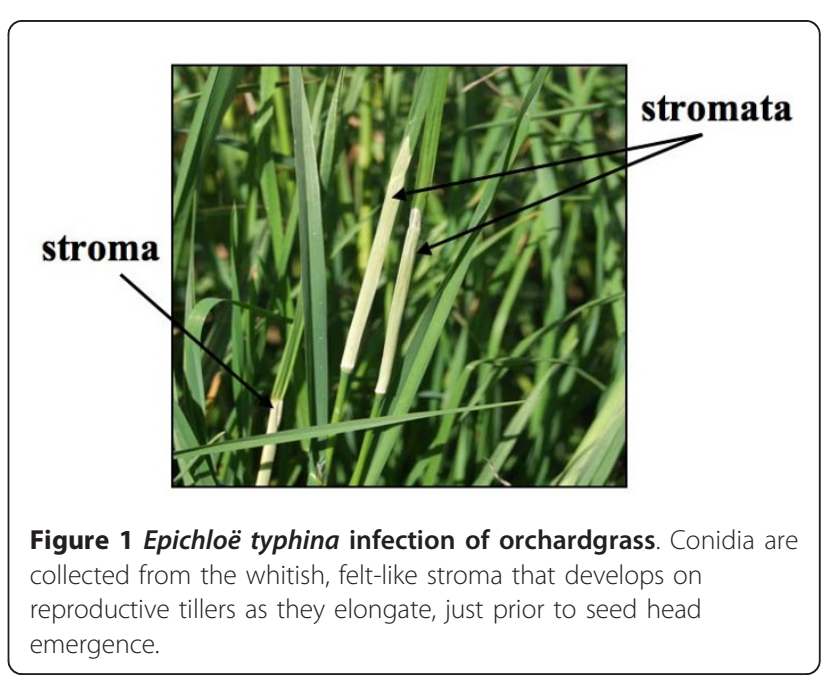


of hygromycin to be used for selection, conidia $(\sim 5000$ conidia/plate) were placed on increasing concentrations of hygromycin B, from $0-400 \mathrm{mg} / \mathrm{L}$, on Corn Meal Malt Agar (CMMA - 19 g corn meal agar, 2 g yeast extract, $20 \mathrm{~g}$ malt extract and $5 \mathrm{~g}$ agar per liter). Since conidia were collected from plants grown in the greenhouse, $150 \mu \mathrm{g} / \mathrm{mL}$ of ampicillin or ticarcillin was added to the selection medium to inhibit bacterial growth.

\section{Determination of optimal electrical field strength for conidia transformation}

Electroporation was performed using the Bio-Rad Gene Pulser II on $100 \mu \mathrm{L}$ of suspended conidia ( 5000 conidia) in a $0.2 \mathrm{~cm}$ cuvette. The percent survival of germinating conidia at various combinations of voltage settings between 1 and $2 \mathrm{kV}$, resistances between 400-800 ohms, and $25 \mu \mathrm{F}$ capacitance was tested. Percent survival at each resistance level (400, 600, 800 ohms) at the three voltages was determined by calculating the number of colonies from each sample (based on colony counts obtained from plating out serial dilutions from each sample) and comparing that to the number of colonies obtained from non-electroporated germinating conidia.

\section{Transformation of conidia}

Approximately $10^{5}-10^{6}$ conidia in $100 \mu \mathrm{L}$ of sterile electroporation buffer were combined with 0.1-2.0 $\mu \mathrm{g}$ of circular or linearized DNA in sterile $500 \mu \mathrm{L}$ microfuge tubes and incubated on ice for $20 \mathrm{~min}$. The DNA/conidial mixture was then transferred into a cold $0.2 \mathrm{~cm}$ electroporation cuvette and subjected to a specific electrical field using Bio-Rad Gene Pulser II. Immediately following the pulse, the conidia were transferred to a sterile $15 \mathrm{~mL}$ snap-cap tube containing $900 \mu \mathrm{L}$ of cold sterile Regeneration Medium (RM - 14.5 g mannitol, $0.4 \mathrm{~g}$ yeast extract and $1.5 \mathrm{~g}$ potato dextrose broth per $100 \mathrm{~mL}$ distilled water). The conidia were incubated on ice for 20-30 min and were then placed on a rotating shaker (150-180 rpm) at room temperature for 5 hours prior to plating on selective solid medium $(200 \mu \mathrm{L} /$ plate). Since conidia were collected from plants grown in the greenhouse, $150 \mu \mathrm{g} / \mathrm{mL}$ of ampicillin or ticarcillin was added to the selection medium to inhibit bacterial growth. Hygromycin B-resistant colonies started to develop in 3-4 weeks. Colonies were examined with a LEICA Fluorescent Dissecting Microscope MZFLIII using a PLANAPO 1.0X Lens to confirm GFP expression in E. typhina transformants. In order to visualize the untransformed control fungus, low intensity white light was used in addition to the UV light.

\section{Southern analysis to determine copy number}

DNA was isolated using a modified CTAB (hexadecyltrimethylammonium bromide) protocol [35] including treatment with RNase. The DNA was treated with Nucleon PhytoPure ${ }^{\mathrm{TM}}$ resin, a component found in the Illustra Nucleon Phytopure ${ }^{\mathrm{TM}}$ Genomic DNA extraction kit (GE Healthcare UK Limited, Buckinghamshire, UK) which covalently binds polysaccharides. Two $\mu \mathrm{L}$ of the resin was added per $100 \mu \mathrm{L}$ of solution, mixed gently, and then centrifuged to pellet the resin. The DNA remained in the supernatant. Approximately $5 \mu \mathrm{g}$ of DNA was digested with EcoRI, using the manufacturer's supplied buffer, and separated in a $1.2 \%$ agarose gel. DNA was transferred to a Hybond-N+ membrane (Amersham; GE Healthcare) by downward capillary transfer following standard protocols [36]. PCR was used to synthesize a digoxigenin (DIG; Roche, Cat. No. 11573152910) labelled probe for a portion of the GFP gene following the recommendations of the company (https://www.roche-applied-science.com). Primers were designed using Primer3 software [37]. Primers for probe synthesis were GFPF64 5'-GACGTAAACGGCCACAAGTTC and GFPR671 5'-GAACTCCAGCAGGACCATGTG producing an amplicon of $\sim 600$ bp (between nucleotide 64 and 671 of the GFP open reading frame). Hybridization and detection were performed following the protocol of Engler-Bloom et al. [38] with modifications described by Krueger and Williams [39].

\section{Results and discussion}

\section{Sensitivity of untransformed conidia to hygromycin B}

When conidia ( $~ 5000$ conidia/plate) were placed on increasing concentrations of hygromycin B on CMMA, many colonies were present on 0 and $100 \mu \mathrm{g} / \mathrm{mL}$ hygromycin, but only a few colonies grew at $200 \mu \mathrm{g} / \mathrm{mL}$, and no colonies grew at 300 and $400 \mu \mathrm{g} / \mathrm{mL}$ hygromycin (Figure 2). Based on this analysis, hygromycin B concentrations of 200 and $300 \mu \mathrm{g} / \mathrm{mL}$ were used for selection of transformants.

\section{Determination of optimal electrical field strength for conidia transformation}

Most reports indicate that the best electroporation conditions to use for transformation are those that result in $40-60 \%$ survival of the cells. With increasing levels of resistance, the 40-60\% survival rate occurred at lower voltages. Approximately $50 \%$ of the conidia survived using $1 \mathrm{kV}$ at $800 \Omega, 1.2 \mathrm{kV}$ at $600 \Omega$, and between 1.2 and $1.5 \mathrm{kV}$ at $400 \Omega$ (Additional file 2).

\section{Transformation of conidia}

Hygromycin B-resistant colonies started to develop in 34 weeks. Transformed colonies grew to a much larger size than untransformed background colonies (Figure 3). Transformation efficiency was greatly affected by use of an intact versus linearized vector and the age of the stroma. The linearized plasmid resulted in a much 


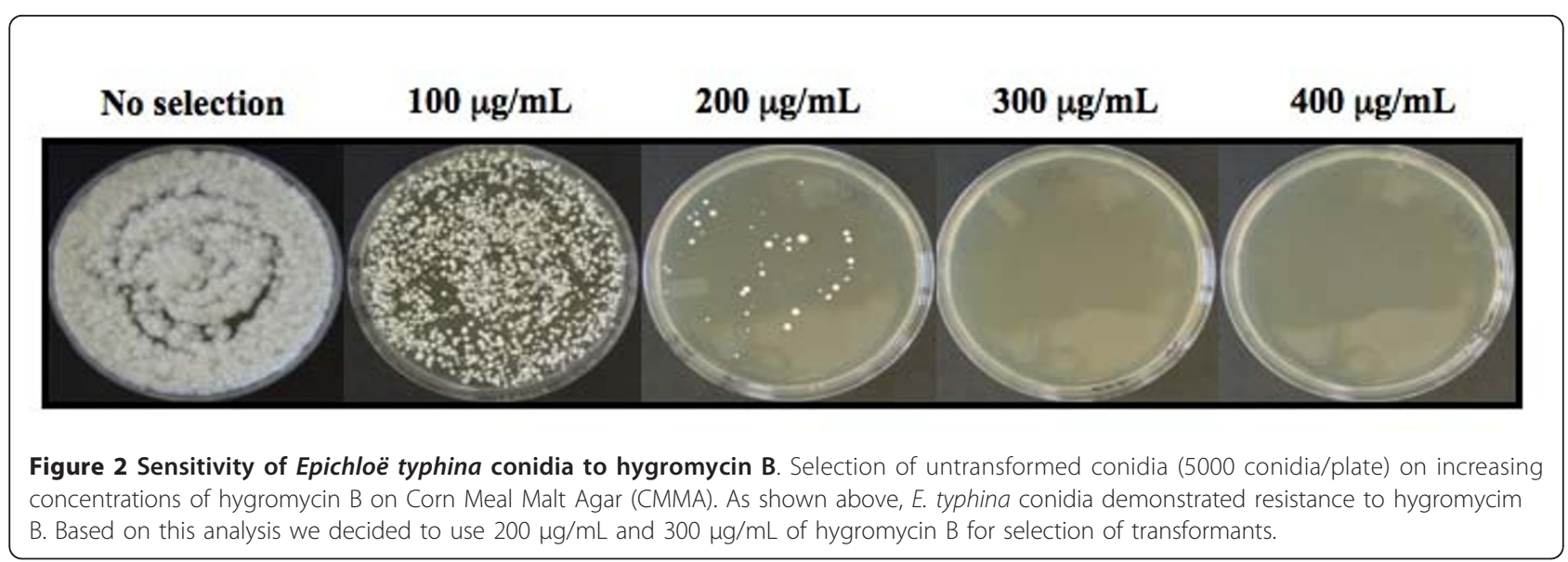

higher frequency of transformation than the circular plasmid which yielded only two transformants. It was also important that conidia were collected from newly formed stroma, as conidia isolated from more mature stroma were not transformable. The greatest number of transformants was obtained at $400 \Omega$ resistance and $1.25 \mathrm{kV}$ at a capacitance of $25 \mu \mathrm{F}$. At resistances of 600 and $800 \Omega$, a voltage of $1.0 \mathrm{kV}$ gave a higher number of transformants compared to what was obtained at 1.25 $\mathrm{kV}$ and $1.5 \mathrm{kV}$ (Table 1$)$.

Over 100 colonies were isolated and over 25 were chosen and stored long term. The percentage of hygromycinresistant colonies expressing GFP was $70-85 \%$ and did not follow a specific pattern in relation to voltage or resistance applied (Table 1). GFP expression levels were variable and different colony morphologies were observed (Figure 4). Over $80 \%$ of the transformed lines continued to express

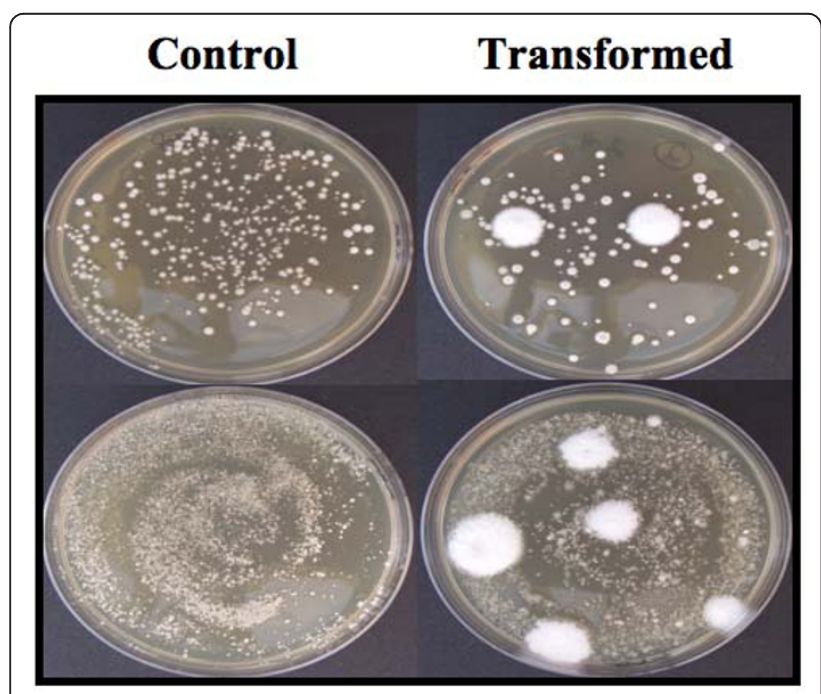

Figure 3 Transformants of Epichloë typhina. Resistant colonies (large) growing on $200 \mathrm{\mu g} / \mathrm{mL}$ hygromycin B CMMA plates (right) and background colonies on control plates (left).
GFP after successive transfers and storage. Fifteen randomly selected lines were verified as E. typhina by PCR using species specific primers (ACT1-F 5'-CCCCGCTC GGCTC-3' and ACT1-R 5'-GCCCAGGCCGAAAAA TTA-3') to produce a $481 \mathrm{bp}$ amplicon from the actin 1 locus which was sequenced [40].

\section{Southern analysis to determine copy number}

Southern analysis was performed to determine copy number for transformed fungal colonies. Approximately $70 \%$ of the lines tested contained single inserts and approximately $23 \%$ had two or three inserts (Figure 5). These 12 lines were found to be stable and were still expressing GFP one year after being established.

\section{Conclusions}

An efficient method for the transformation of germinating conidia of E. typhina by electroporation was

Table 1 Number of hygromycin-resistant colonies expressing GFP at designated electroporation conditions

\begin{tabular}{cccccccc}
\hline & & \multicolumn{2}{c}{ \# GFP/total \# Hyg $^{\mathbf{R}}$ colonies } & \multicolumn{2}{c}{ Overall } \\
\cline { 3 - 8 } $\boldsymbol{\Omega}$ & $\mathbf{k V}$ & $\mathbf{1}$ & $\mathbf{2}$ & $\mathbf{3}$ & $\mathbf{4}$ & GFP/Hyg & \%GFP \\
\hline $\mathbf{4 0 0}$ & 1 & $26 / 28$ & $23 / 35$ & $18 / 24$ & $20 / 26$ & $87 / 113$ & 77 \\
\hline $\mathbf{4 0 0}$ & 1.25 & $36 / 45$ & $28 / 37$ & $26 / 39$ & $41 / 48$ & $131 / 169$ & 78 \\
\hline $\mathbf{4 0 0}$ & 1.5 & $15 / 19$ & $18 / 21$ & $17 / 20$ & $27 / 32$ & $77 / 92$ & 84 \\
\hline $\mathbf{6 0 0}$ & 1 & $25 / 33$ & $30 / 37$ & $19 / 27$ & $21 / 26$ & $95 / 123$ & 77 \\
\hline $\mathbf{6 0 0}$ & 1.25 & $20 / 25$ & $14 / 19$ & $20 / 23$ & $15 / 19$ & $69 / 86$ & 80 \\
\hline $\mathbf{6 0 0}$ & 1.5 & $6 / 10$ & $17 / 20$ & $10 / 14$ & $5 / 10$ & $38 / 54$ & 70 \\
\hline $\mathbf{8 0 0}$ & 1 & $27 / 41$ & $18 / 27$ & $18 / 22$ & $25 / 33$ & $88 / 123$ & 72 \\
\hline $\mathbf{8 0 0}$ & 1.25 & $12 / 15$ & $4 / 5$ & $7 / 8$ & $9 / 10$ & $32 / 38$ & 84 \\
\hline $\mathbf{8 0 0}$ & 1.5 & $9 / 10$ & $12 / 14$ & $10 / 13$ & $9 / 10$ & $40 / 47$ & 85 \\
\hline
\end{tabular}

Electroporation was performed at combinations of three different resistances $(400,600,800 \Omega)$ and three different voltages $(1.0,1.25$, and $1.5 \mathrm{kV})$ at $25 \mu \mathrm{F}$ capacitance. The number of GFP expressing colonies and the total number of hygromycin-resistant colonies obtained from four different experiments at designated electroporation conditions are indicated in the table. Combined results of the four experiments are also presented. 


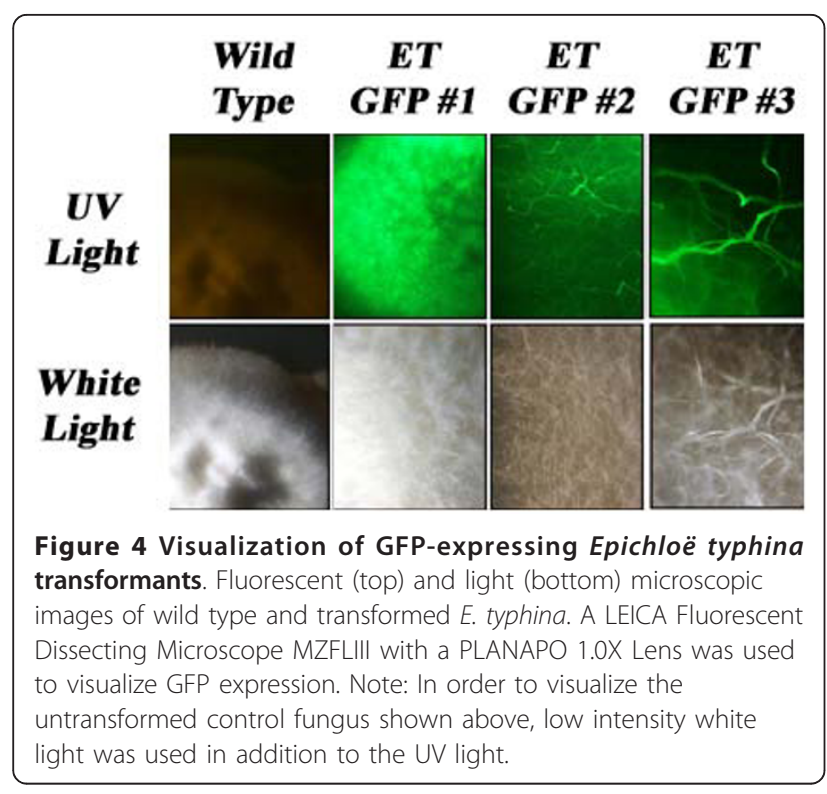

established. Two critical parameters for successful transformation were the use of a linearized plasmid and conidia that were collected from newly formed stromata. Transformed fungi were selected on 200 and $300 \mu \mathrm{g} / \mathrm{mL}$ hygromycin B. Over $80 \%$ of transformed lines continued to express GFP after successive transfers and storage. Fifteen lines were chosen and have been maintained for over 5 years and are still expressing GFP. We observed variable levels of GFP expression and some different colony morphologies. The selected isolates were verified as E. typhina by sequencing the PCR products obtained using species specific primers for the actin 1 locus. Southern analysis revealed the presence of a single insert in $70 \%$ of the lines tested. The GFP labelled E. typhina lines provide a valuable molecular tool to researchers studying conditions and mechanisms involved in the establishment of choke in orchardgrass. While the mode of infection for E. typhina in orchardgrass is uncertain, several researchers have successfully introduced $E$. typhina into perennial ryegrass and orchardgrass $[5,41]$ however, it was not determined if the inoculated plants would ultimately manifest choke symptoms. It will be interesting to see if these methods will work to introduce the GFP expressing E. typhina into orchardgrass, and more importantly, if that will lead to the manifestation of choke disease in subsequent years. This would allow monitoring of the infection process under natural mechanisms of infection which would be quite different from artificial methods of inoculation.

\section{Additional material}

Additional file 1: Germination of collected conidia. Isolated conidia were gently shaken in deionized water for 4 hours at room temperature. After 4 hours greater than $90 \%$ of conidia had germinated.

Additional file 2: Effect of electrical field strength on germinated conidia viability. Electroporation was performed using the Bio-Rad Gene Pulser II with different voltages and resistances at $25 \mu \mathrm{F}$ capacitance on $100 \mu \mathrm{L}$ of suspended conidia in a $0.2 \mathrm{~cm}$ cuvette. The best

electroporation conditions to use for transformation are those that result in $40-60 \%$ survival of the cells (between the green lines).

\section{Abbreviations}

GFP: Green Fluorescent Protein; CMMA: Corn Meal Malt Agar; NaOAc: Sodium Acetate; EtOH: Ethanol; $\mu \mathrm{F}$ : microfarad; RNase: ribonuclease; kV: kilovolts; $\Omega$ : Ohms.

\section{Acknowledgements}

Special thanks are extended to Dr. Jennifer M. Lorang and Dr. Lynda M. Ciuffetti, Department of Botany and Plant Pathology, Oregon State University, for providing the PCT74 plasmid. Experimental methods performed in this research complied with current laws and regulations of the U.S.A. The use of trade, firm, or corporation names in this publication is for the information and convenience of the reader. Such use does not constitute an official endorsement or approval by the United States Department of Agriculture or the Agricultural Research Service of any product or service to the exclusion of others that may be suitable. Relevance to ARS National Programs. NP205: Rangeland, Pasture and

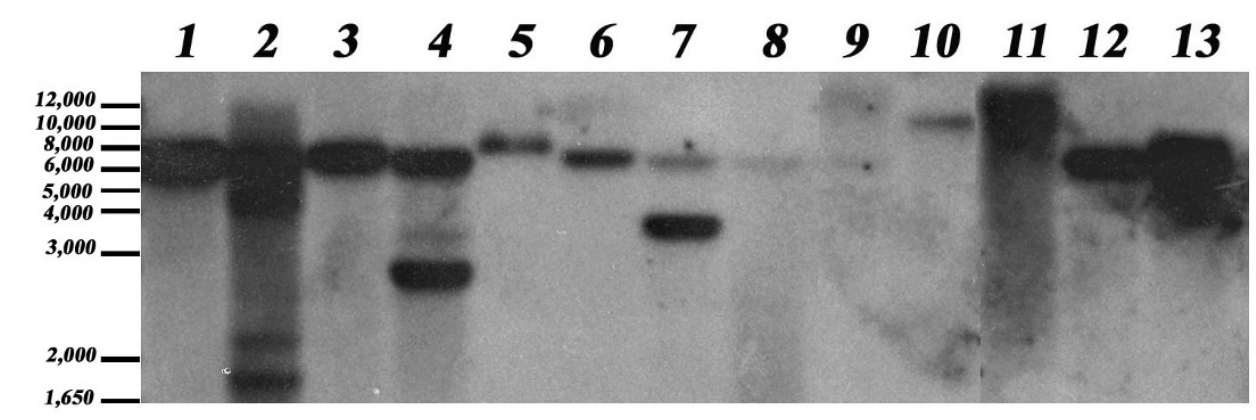

Figure 5 Southern blot analysis of transformed Epichloë typhina lines. Genomic DNA was digested with EcoRl and probed with a portion of the GFP gene (608 bp amplicon between nucleotide 64 and 671 of the GFP open reading frame) that was labelled with digoxigenin. The presence of a single band in most lanes indicates a single insertion event in those transformed lines. The different size of the bands indicates unique transformation events. 
Forages: Component "Plant Resources". NP302: Plant Biological and Molecular Processes: Component "Biological Processes that Determine Plant Productivity and Quality". and NP303 Plant Diseases: Component "Pathogen Biology, Genetics, Population Dynamics, Spread, and Relationship with Hosts and Vectors".

\section{Author details}

${ }^{1}$ USDA-ARS National Forage Seed Production Research Center, 3450 S.W. Campus Way, Corvallis, OR 97331 USA. ${ }^{2}$ Applied Technology Center, 2484 Gillingham Drive, B-175W Brooks City-Base, TX 78235 USA.

\section{Authors' contributions}

JED, SCA and JCB conceived the study and participated in its design. SCA provided the fungal materials. JED and JCB carried out the transformation experiments and helped to draft the manuscript. RCM performed the Southern analysis and helped write the manuscript. All authors read and approved the final manuscript.

\section{Competing interests}

The authors declare that they have no competing interests.

Received: 21 September 2010 Accepted: 5 March 2011

Published: 5 March 2011

\section{References}

1. Alderman SC, Pfender WF, Welty RE, Mellbye ME, Cook RL, Spatafora JW, Putnam M: First report of choke caused by Epichloë typhina on orchardgrass in Oregon. Plant Dis 1997, 81:1335-1339.

2. Rao S, Baumann D: The interaction of a Botanophila fly species with an exotic Epichloë fungus in a cultivated grass: Fungivore or mutualist? Entomol Exp Appl 2004, 112:99-105.

3. Sampson K: The systemic infection of grasses by Epichloë typhina (Pers.) Tul. Trans Brit Mycol Soc 1933, 18:30-47.

4. Western JH, Cavett JJ: The choke disease of cocksfoot (Dactylis glomerata) caused by Epichloë typhina (Fr.) Tul. Trans Brit Mycol Soc 1959, 42:298-307.

5. Chung KR, Hollin W, Siegel MR, Schardl CL: Genetics of host specificity in Epichloë typhina. Phytopathology 1997, 87:599-605.

6. Chung KR, Schardl CL: Sexual cycle and horizontal transmission of the grass symbiont, Epichloë typhina. Mycol Res 1997, 101:295-301.

7. Pfender WF, Alderman SC: Geographic distribution and incidence of orchardgrass choke caused by Epichloë typhina in Oregon. Plant Dis 1999, 83:754-758.

8. Pfender WR, Alderman SC: Regional development of orchardgrass choke disease and estimation of seed yield loss. Plant Dis 2006, 90:240-244.

9. Large EC: Surveys for choke (Epichloë typhina) in cocksfoot seed crops 1951-1953. Plant Pathol 1954, 3:6-11.

10. Raynal GE: Libération des ascospores d'Epichloë typhina, agent de la quenouille du dactyle: Conséquences pour l'épidémiologie et la lutte. Fourrages 1991, 127:345-358.

11. Fermaud $M$ : Epidémiologie de la quenouille du dactyle porte-graine due à Epichloë typhina (Pers. ex Fr.) Tulasne. PhD Thesis, Ecole Nationale Supérieure d'Agronomie, Montpellier, France 1986.

12. Bultman TL, White JF, Bowdish TI, Welch AM, Johnston JJ: Mutualistic transfer of Epichloë spermatia by Phorbia flies. Mycologia 1995, 87:182-189.

13. Kaser JM, Rao S: Mapping the choke pathogen in cultivated orchardgrass fields in the Willamette Valley. In Seed production research at Oregon State University USDA-ARS cooperating. Volume 129. Edited by: Young W III. Dept. of Crop and Soil Science Ext/CrS; 2009:1-5.

14. Alderman SC, Rao S: Ascosporic fertilization of Epichloë typhina in Dactylis glomerata seed production fields in Oregon and implications for choke management. Plant Health Prog 2008.

15. Leyronas C, Raynal G: Role of fungal ascospores in the infection of orchardgrass (Dactylis glomerata) by Epichloë typhina agent of choke disease. J Plant Pathol 2008, 90:15-21.

16. Lorang JM, Tuori RP, Martinez JP, Sawyer TL, Redman RS, Rollins JA, Wolpert TJ, Johnson KB, Rodriguez RJ, Dickman MB, Ciuffetti LM: Green fluorescent protein is lighting up fungal biology. Appl Environ Microbiol 2001, 67:1987-1994.
17. Liu T, Liu L, Hou J, Li G, Gao S, Chen J: Expression of green fluorescent protein in Curvularia lunata causing maize leaf spot. Can J Plant Pathol 2010, 32:225-228.

18. Mansouri S, van Wijk R, Rep M, Fakhoury AM: Transformation of Fusarium virguliforme, the causal agent of sudden death syndrome of soybean. $J$ Phytopathol 2009, 157:319-320.

19. Pliego C, Kanematsu S, Ruano-Rosa D, de Vicente A, López-Herrera C, Cazorla FM, Ramos C: GFP sheds light on the infection process of avocado roots by Rosellinia necatrix. Fungal Genet Biol 2009, 46:137-145.

20. de Silva AP, Bolton MD, Nelson BD: Transformation of Sclerotinia sclerotiorum with the green fluorescent protein gene and fluorescence of hyphae in four inoculated hosts. Plant Pathol 2009, 58:487-492.

21. Maruthachalam K, Nair V, Rho HS, Choi J, Kim S, Lee YH: Agrobacterium tumefaciens-mediated transformation in Colletotrichum falcatum and C. acutatum. J Microbiol Biotechnol 2008, 18:234-241.

22. Sukno SA, Garcia VM, Shaw BD, Thon MR: Root infection and systemic colonization of maize by Colletotrichum graminicola. Appl Environ Microbiol 2008, 74:823-832.

23. Heneghan MN, Porta C, Zhang C, Burton KS, Challen MP, Bailey AM, Foster GD: Characterization of serine proteinase expression in Agaricus bisporus and Coprinopsis cinerea by using green fluorescent protein and the A. bisporus SPR1 promoter. Appl Environ Microbiol 2009, 75:792-801.

24. Richey MG, Marek ET, Schardl CL, Smith DA: Transformation of filamentous fungi with plasmid DNA by electroporation. Phytopathology 1989, 79:844-847.

25. Gold SE, Duick JW, Redman RS, Rodriguez RJ: Molecular transformation, gene cloning, and gene expression for filamentous fungi. In Applied Mycology and Biotechnology. Volume 1. Edited by: Khachatourians GG, Aroua DP. Oxford, UK: Elsevier Science; 2001:199-238.

26. Michielse CB, Hooykaas PJJ, van den Hondel CAMJJ, Ram AFJ: Agrobacterium-mediated transformation as a tool for functional genomics in fungi. Curr Genet 2005, 48:1-17.

27. Meyer V: Genetic engineering of filamentous fungi - Progress, obstacles and future trends. Biotechnol Adv 2008, 26:177-185.

28. Lianhui J, Jiang ZD, Liu Y, Koh CMJ, Zhang LH: A simplified and efficient method for transformation and gene tagging of Ustilago maydis using frozen cells. Fungal Genet Biol 2010, 47:279-287.

29. Betts MF, Tucker SL, Galadima N, Meng Y, Patel G, Li L, Donofrio N, Floyd A, Nolin S, Brown D, Mandel MA, Mitchel TK, Xu JR, Dean RA, Farman ML, Orback MJ: Development of high throughput transformation system for insertional mutagenesis in Magnaporthe oryzae. Fungal Genet Biol 2007, 44:1035-1049.

30. May KJ, Bryant MK, Zhang X, Ambrose B, Scott B: Patterns of expression of a lolitrem biosynthetic gene in Epichloë festucae-perennial ryegrass symbiosis. Mol Plant-Microbe Interact 2008, 21:188-197.

31. Christensen MJ, Bennett RJ, Ansari HA, Koga H, Johnson RD, Bryan GT, Simpson WR, Koolaard JP, Nickless EM, Voisey CR: Epichloë endophytes grow by intercalary hyphal extension in elongating grass leaves. Fungal Genet Biol 2008, 45:84-93.

32. Marchand G, Fortier E, Neveu B, Bolduc S, Belzile F, Bélanger RR: Alternative methods for genetic transformation of Pseudozyma antarctica, a basidiomycetous yeast-like fungus. J Microbiol Methods 2007, 70:519-529.

33. Lakshmi Prabha V, Punekar NS: Genetic transformation of Aspergilli: Tools of the trade. Indian J Biochem Biophys 2004, 41:205-215.

34. Dobrowolska A, Staczek P: Development of transformation system for Trichophyton rubrum by electroporation of germinated conidia. Curr Genet 2009, 55:537-542.

35. Doyle JJ, Doyle JL: Isolation of plant DNA from fresh tissue. Focus 1990, 12:13-15.

36. Sambrook J, Russell DW: Molecular Cloning, A Laboratory Manual. Cold Spring Harbor, Cold Spring Harbor Press, New York; 2001.

37. Rozen S, Skaletsky HJ: Primer3 on the WWW for general users and for biologist programmers. In Bioinformatics Methods and Protocols: Methods in Molecular Biology. Edited by: Misener S, Krawetz SA. Totowa, New Jersey: Humana Press; 2000:365-386

38. Engler-Blum G, Meier M, Frank J, Müeller GA: Reduction of background problems in nonradioactive Northern and Southern blot analyses enables higher sensitivity than ${ }^{32} \mathrm{P}$-based hybridizations. Anal Biochem 1993, 210:235-244

39. Krueger SK, Williams DE: Quantification of digoxigenin-labeled DNA hybridized to DNA and RNA slot blots. Anal Biochem 1995, 229:162-169. 
40. Baldwin JC, Dombrowski JE, Alderman SC: A DNA assay for the detection of choke in orchardgrass. In Seed production research at Oregon State University USDA-ARS cooperating. Volume 124. Edited by: Young W III. Dept. of Crop and Soil Science Ext/CrS; 2004:19-20.

41. Latch GCM, Christensen MJ: Artificial infections of grasses with endophytes. Ann Appl Biol 1985, 107:17-24.

doi:10.1186/1756-0500-4-46

Cite this article as: Dombrowski et al:: Transformation of Epichloë

typhina by electroporation of conidia. BMC Research Notes 2011 4:46.

Submit your next manuscript to BioMed Central and take full advantage of:

- Convenient online submission

- Thorough peer review

- No space constraints or color figure charges

- Immediate publication on acceptance

- Inclusion in PubMed, CAS, Scopus and Google Scholar

- Research which is freely available for redistribution

Submit your manuscript at www.biomedcentral.com/submit 